\title{
How Novice EFL Teachers Regulate Their Negative Emotions
}

\author{
Cómo los maestros principiantes de inglés como lengua \\ extranjera regulan sus emociones negativas*
}

Silvia Arizmendi Tejeda silviaarizmenditejeda@yahoo.com

\section{Barbara Scholes Gillings de González \\ bascholes@uv.mx}

\section{Cecilio Luis de Jesús López Martínez celopez@uv.mx Universidad Veracruzana, Veracruz, Mexico}

\begin{abstract}
This research report shares the findings that emerged from a qualitative study in which the main objective was to discover whether or not novice English as a foreign language teachers regulate their negative emotions during their initial teaching practice, and if so, how they do this. The data were collected by semi-structured interviews and observations, and analyzed by microanalysis and constant comparative analysis. The participants were five novice teachers who study English at the same university, and who were giving classes as part of their internship. The results from this research revealed that these particular novice English as a foreign language teachers use different emotional strategies to regulate their negative emotions.
\end{abstract}

* Received: June 30, 2015. Accepted: February 22, 2016.

How to cite this article (APA 6th ed.):

Arizmendi Tejeda, S., Gillings de González, B. S., \& López Martínez, C. L. (2016). How novice EFL teachers regulate their negative emotions. HOW, 23(1), 30-48. http://dx.doi.org/10.19183/how.23.1.299.

This article is licensed under a Creative Commons Attribution-NonCommercial-NoDerivatives 4.0 International License. License Deed can be consulted at http://creativecommons.org/licenses/by-nc-nd/4.0/. 
Key words: Emotional regulation, emotions, novice EFL teachers, stages, strategies.

El propósito de este reporte de investigación es compartir los hallazgos de un estudio cualitativo cuyo objetivo principal fue descubrir si los maestros principiantes de inglés como lengua extranjera regulan sus emociones negativas durante su práctica inicial y de ser así, cómo lo hacen. La información fue recolectada usando entrevistas semi-estructuradas y observaciones. Dicha información fue analizada usando microanálisis y análisis de constante comparación. Los participantes de esta investigación son cinco maestros principiantes que estudian inglés en la misma universidad y que como servicio social estaban impartiendo clases. Los resultados de la investigación revelan que estos maestros principiantes de inglés como lengua extranjera usan diferentes estrategias emocionales para regular sus emociones negativas.

Palabras clave: emociones, estrategias, etapas, maestros principiantes de inglés como lengua extranjera, regulación emocional.

\section{Introduction}

Human beings are defined by their ability to rationalize. We have the ability to analyze different situations and make decisions based on logic. However, humans are not only rational, but also emotional. It is not possible to isolate our emotions and only act logically, given that, as some authors argue, emotions regulate our acts. Baier (2004) claims that, "emotions or lack of them ... speak the truth about if and how much something matters to us" (p. 207). Moreover, Méndez and Peña (2013) have established that "language learning is a process replete with negative and positive emotions [and consequently] the creation of a positive learning environment should therefore be the first aim language teachers strive for" (p. 13). However, in order to create a positive learning environment, teachers need to work on their emotions as well as those of their students'. Consequently, emotions play an important role in English as a foreign language (EFL) teaching, so much so that teaching involves a great deal of emotional labor; that is, the manufacture or masking of the teachers' emotions in order to generate a positive response in others. When planning, organizing, and managing a class, the teacher needs to engage with his/her students and care about them. However, caring involves both "negative and positive emotional labor" (Isenbarger \& Zembylas, 2006, p. 124). This is because in his/her relationship with students, the teacher may experience great satisfactions and/or disappointments. This emotional labor is quite difficult for every teacher, but especially for a novice EFL teacher.

A way to deal with this emotional labor is by regulating our emotions. In this respect, Gross (2002) describes emotional regulation as the ability to control the experience and the expressions of emotions. In other words, by regulating our emotions we are aware of whether or not we can control them. Emotional regulation may be very useful in teaching practice because teachers face different situations that make them feel a great variety of emotions, and 
they need to find a way to deal with them. Regulating our emotions is necessary because, as Gross comments, sometimes emotions and emotional responses do more harm than "good." For example, if a teacher displays frustration or a lack of satisfaction within the classroom, students may feel embarrassed by their own performance and so become de-motivated. In sum, emotions play an important role in teaching; however, they need to be regulated.

Additionally, although researchers have made progress towards identifying the role of emotions in education (e.g., Linnenbrink, 2006; Nias, 1996; Schutz \& Lanehart, 2002; Schutz \& Pekrun, 2007; van Veen \& Lasky, 2005), there is still a need for researchers to study how emotions may influence EFL teaching and student learning, given that research on these topics is scarce (Méndez, 2011; Méndez \& Fabela, 2014; Méndez \& Peña, 2013). For instance, Méndez (2011) claims that "although the process of learning a foreign language is replete with emotions, these have not been sufficiently studied in the field of English Language Teaching" (p. 45). Moreover, Fried (2011) argues that

a greater understanding of the role of emotions in the teaching profession can help in the training of teachers to be well equipped to tackle the demands of the classroom and achieve the goal of educating students who can take greater control of their lives. (p. 8)

Thus, this paper may be helpful for novice teachers who are about to start teaching since it may provide them with an idea of how they may regulate their emotions so as not to let these affect their teaching practice and/or a student's learning process.

\section{Research Questions}

The main objective of this inquiry was to discover how novice teachers regulate their emotions during their initial practice. In order to discover this, the following questions were designed.

\section{Main Research Question}

- How do novice EFL teachers regulate their negative emotions during their initial practice?

\section{Research Sub-Questions}

- How do novice EFL teachers feel during their initial teaching practice?

- When and why do novice EFL teachers regulate their negative emotions?

- What strategies do novice EFL teachers use to regulate their negative emotions?

This report is comprised of three sections. First, the emotional dimension of teaching is discussed and the following concepts are explained: emotional intelligence, emotional 
understanding, teaching as an emotional labor, novice teachers' emotional stages and emotional regulation. Then, the methodology employed in this research project is explained. Here, information about qualitative research is provided, including the way in which the data were collected and analyzed. The research context, the participants, and the research procedure are also described. Finally, the findings obtained from this qualitative research study are presented and analyzed.

\section{The Emotional Dimension of Teaching}

Although many writers have now been focusing on the emotional dimension in teaching, it is still rather difficult to define this dimension owing to all its different facets. The main ones are discussed below.

\section{Emotional Intelligence}

Goleman (2005) explains that the Aristotle challenge consists in managing our emotional life with intelligence. Humans are emotional beings by nature. It is not possible to separate our cognitive side from our emotional side. Emotions guide our actions, but emotions can easily go awry. They can occur at the wrong time, with the wrong person, or with the wrong intensity. However, the problem is not emotionality, but the appropriateness of emotion and its expression. In order to manage our emotional life with intelligence, it is necessary to develop our emotional intelligence.

The term emotional intelligence was first proposed by Salovey and Mayer (1990). However, it was popularized by Goleman's book Emotional intelligence (1995). Emotional intelligence consists in the skills shown in Figure 1.

Thus, emotional intelligence is very important in teaching, since it allows teachers not only to recognize their emotions and to manage them in the most appropriate way, but also to recognize emotions in students and in this way establish a positive and rewarding relationship with them. Moreover, emotional intelligence allows teachers to motivate themselves in order to accomplish the goals they have established, such as helping students to speak in English, to acquire a good or adequate reading level, or simply to learn some vocabulary. Consequently, by motivating themselves, teachers also motivate their students.

\section{Emotional Understanding}

Teaching is an emotional practice which involves creating relationships with students. However, it is important to remember that teachers as well as students are emotional beings. Teachers are supposed to motivate students, to connect with them, and to understand them 
even when students do not say a word. In order to carry out this task, teachers need emotional understanding. Denzin (1984) explains emotional understanding as:

An intersubjective process requiring that one person enter into the field of experience of another and experience for herself the same or similar experiences experienced by another. The subjective interpretation of another's emotional experience from one's own standpoint is central to emotional understanding. Shared and shareable emotionality lie at the core of what it means to understand and meaningful enter into the emotional experiences of another. (p. 137)

\begin{tabular}{|c|c|}
\hline $\begin{array}{c}\text { Knowing one's } \\
\text { emotions }\end{array}$ & $\begin{array}{l}\text { Self-awareness. Recognizing a feeling as it happens. People } \\
\text { with a greater certainty about their feelings are better pilots of } \\
\text { their lives. }\end{array}$ \\
\hline $\begin{array}{l}\text { Managing } \\
\text { emotions }\end{array}$ & $\begin{array}{l}\text { Handling feelings so they are appropriate is an ability that builds } \\
\text { on self-awareness. The capacity to soothe oneself. People who } \\
\text { are poor in this ability are constantly battling feelings of distress. }\end{array}$ \\
\hline $\begin{array}{l}\text { Motivating } \\
\text { oneself }\end{array}$ & $\begin{array}{l}\text { Marshaling emotions in the service of a goal. People who have } \\
\text { this skill tend to be more highly productive and effective in } \\
\text { whatever they undertake. }\end{array}$ \\
\hline
\end{tabular}

\begin{tabular}{|c|c|c|c|c|c|}
$\begin{array}{c}\text { Recognizing } \\
\text { emotions } \\
\text { in others }\end{array}$ & $\begin{array}{l}\text { Empathy, another ability that builds on emotional self- } \\
\text { awareness. It is the fundamental "people skill." People who are } \\
\text { empathic are more attuned to the subtle social signals that } \\
\text { indicate what others need or want. }\end{array}$ \\
\begin{tabular}{|l} 
Handling \\
relationships
\end{tabular} & $\begin{array}{l}\text { The art of relationships is a skill in managing emotions in others. } \\
\text { It requires abilities that undergird popularity, leadership, and } \\
\text { interpersonal effectiveness. People who excel in this do well at } \\
\text { anything that relies on interacting with others. }\end{array}$ \\
\hline
\end{tabular}

Figure 1. Emotional Intelligence (Adapted From Goleman, 2005, pp. 43-44)

In simpler words, emotional understanding consists in putting yourself in someone else's shoes and to understand things from his/her point of view. It means to be empathetic. Denzin (1984) argues that teaching draws upon emotional understanding as people "reach into the past store of their own emotional experience to interpret and unravel, instantaneously, at-a-glance, the emotional experiences and responses of others" (p. 1059). 
Emotional understanding can be established through emotional infection (spreading optimistic or pessimistic moods to others), sharing feelings in common with others, sharing emotional experiences in long-standing relationships, or when we just empathize with people (Denzin, 1984).

Teachers use emotional understanding to recognize and interpret emotions such as fear, happiness, sadness, anger, and joy, among others, in their students. However, teachers may also misunderstand. Emotional misunderstanding occurs when teachers think they know what their students are feeling, but they are completely wrong. They may misunderstand their students' exuberance for hostility, bored compliance for studious commitment, or silent respect for sullen resistance (Hargreaves, 1998). Hence, according to Hargreaves (2001), "if we misunderstand how students are responding, we misunderstand how they learn" (p. 1060). Therefore, successful teaching and learning depend on establishing close bonds with students in order to achieve emotional understanding.

\section{Teaching as Emotional Labor}

Teaching is a very demanding profession. It involves creating relationships with students and having the ability to recognize and interpret their emotions, but most of all, it involves caring. Bullough (2011) argues that "despite how physically, cognitively, and emotionally demanding teaching is, on the whole teachers are resilient people who care deeply about those they teach and the work of teaching. Therefore, teaching is an emotional labor" (p. 34).

In this regard, Hochschild (as cited in Hargreaves, 1998) states that emotional labor:

requires one to induce or suppress feelings in order to sustain the outward countenance that produces the proper state of mind in others... This kind of labor calls for a coordination of mind and feeling, and it sometimes draws on a source of self that we honor as deep and integral to our personality. (p. 840)

In other words, emotional labor requires people to manufacture or mask their emotions. For example, an employee who has to hear complaints all day needs to remain calm in order to answer the customer's complaints with respect. Other examples would be a polite waitress, or an enthusiastic salesman. Teachers manufacture and mask their emotions in different situations in order to generate a response in their students. For example, when they show surprise at something students say, are overjoyed with a student's breakthrough, show patience with a colleague, or are calm when a parent criticizes them. Teachers are commonly expected to "smile and appear cheerful on days when they are not quite up to par and would rather be somewhere else" (Jackson et al., as cited in Hargreaves, 1998, p. 840). This is why teaching is a form of emotional labor that teachers exercise every day. Thus, emotional regulation is intertwined with emotional labor as in order to regulate their emotions, teachers have to work with their emotions and even mask them. 


\section{Novice Teachers' Emotional Stages}

Ryan (1986) claims that teachers go through four emotional stages: fantasy, survival, mastery, and impact. The first two stages concern novice teachers.

In the first stage, fantasy, novice teachers have not been in the classroom as teachers and they can only imagine what being a teacher will be like. They have fantasies about what their students will be like and the pleasant environment that they think they will have in their classrooms. This stage is characterized by an unrealistic positivism as voiced in the example below.

I will be very mature and loving. The students will respect me for how hard I work. I will have such respect that I will never have to raise my voice. No one will want to misbehave, afraid of losing my favor. (A pre-service student teacher in Ryan, 1986, p. 11)

In the "survival" stage, novice teachers fight for their professional concept of self when discipline and management problems are present. Novice teachers look for a sense of worth. Moreover, if students do not learn, novice teachers take this as a personal failure. This stage occurs during the first year and, according to Ryan (1986), teachers are confronted with a problem that they cannot ignore or blame someone else for. Thus, they can either choose to try another profession or confront the problem and struggle to succeed.

The "mastery" stage takes places when a teacher "begins to learn the craft of teaching in a step by step fashion" (Ryan, 1986, p. 14). During this stage, self-confidence and hope grow. Teachers realize that their actions have positive effects and they no longer take everything as a personal failure. Teachers who are at this stage are guided by a good attitude, and experience usually takes them to the next stage.

Teachers enter the "impact" stage once they have more experience and have reflected on the situations they have experienced during their teaching practice. During this stage, teachers know what to do in different situations and they are supposed to have mastered the skills of teaching.

\section{Emotional Regulation}

Gross (1998) describes emotional regulation as the ability to control the experience and the expressions of emotions. This is the process by which individuals influence which emotions they have, when they have them, and how they express these emotions. By regulating our emotions, we become aware of them and are capable of controlling them. Twenge and Baumeister (2002) argue that "the human ability to regulate oneself and alter a person's own responses is one of the most powerful and adaptive capacities that people have and is probably responsible for the immense diversity and flexibility of human behavior"' (p. 57). 
Emotional regulation may be very useful when teaching, since teachers have to deal with different emotions during their practice. Even though teaching is an emotional practice, this does not imply that all teachers feel the same. Teachers may experience different emotions under the same circumstances because they may interpret students' behavior from their own particular perspective. For example, a child who does not work may trigger anger in one teacher and frustration or sadness in another. In which moment a teacher may feel an emotion also varies, that is, "a teacher may experience surprise at a student's question as soon as the question is asked or after school when she is reflecting on the lesson" (Sutton, 2004, p. 380).

Emotional regulation also has to do with the way we express our emotions. A teacher may want to shout for joy when a child understands a rule or a concept that has been difficult for him/her, but instead, the teacher says "good job" or "well done." In the same way, a teacher who is angry at one child may want to shout, but instead s/he may just call the child's attention. Gross (1998) classified the strategies of emotional regulation into two main categories, preventative (antecedent-focused) and responsive (response-focused) as shown in Figure 2.

The preventative strategies are: selecting situations, modifying situations, attention deployment, and cognitive change. When selecting a situation, the teacher may choose to teach only children, because $\mathrm{s} /$ he may find it difficult to work with teenagers. A teacher may modify a situation by not letting

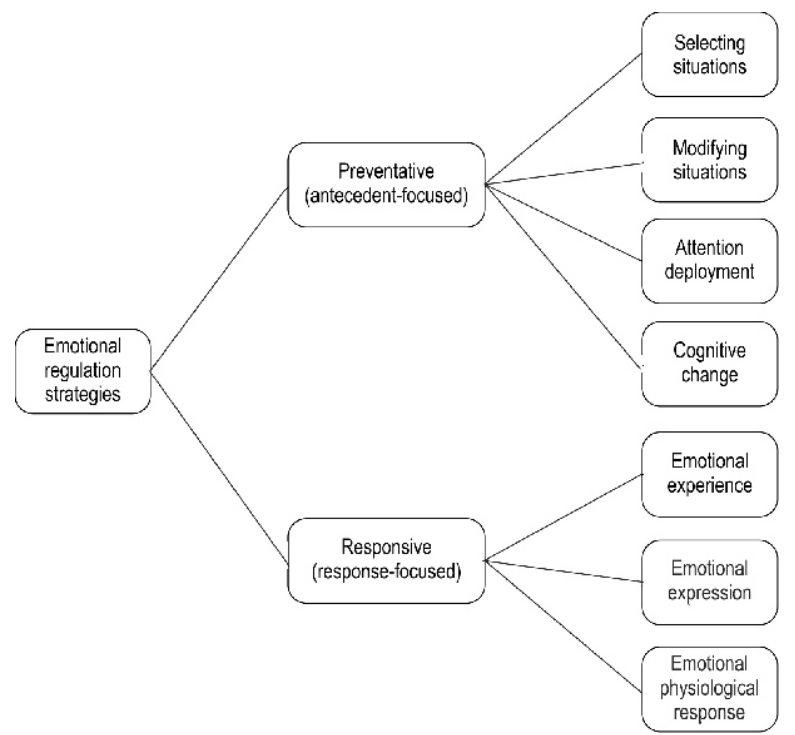

Figure 2. Emotional Regulation (Based on Gross, 1998, and Sutton, 2004) 
children, who always talk in the classroom, sit together. Attention deployment is used when before the class the teacher focuses on being enthusiastic and energetic. When a teacher realizes that a child misbehaves because $\mathrm{s} /$ he has troubles at home, the teacher again assesses the situation, and because of this cognitive change, instead of being angry, feels empathy.

Responsive emotional regulation occurs after the emotion has already been triggered. It acts to "intensify, diminish, prolong or curtail the ongoing emotional experiences, expression or physiological responding" (Gross, 1998, p. 225). Responsive strategies are: emotional change, emotional expression, and emotional physiological response. Self-talk may modify the experience, deep breathing could be used to relieve the psychological response, and the emotional expression could be modified by controlling facial expressions (Sutton, 2004). Moreover, the "emotional regulation strategies that teachers could use after the class is over include exercising or talking to peers" (Sutton, 2004, p. 382).

\section{Method}

\section{Qualitative Research}

In qualitative research, information about beliefs, feelings, motivations, and values, conveyed through language and behavior is analyzed. Flick (2009) claims that in qualitative research people are not reduced to single variables, but represented in their entirety in their everyday context. Therefore, the fields of study are not artificial situations in the laboratory, but the practices and interactions of people in everyday life. Qualitative researchers study people in their natural settings in a particular time and context. Patton (as cited in Merriam, 2002), states that qualitative research tries to understand situations in their uniqueness as part of a particular context. Qualitative research does not attempt to predict what may happen in the future, but to understand the nature of a particular setting, what it means for participants to be in that setting, what their lives are like, and what the world looks like in that specific context.

\section{Data Collection Methods}

In this research, data were collected by semi-structured interviews (see Appendix), observations, in which the researcher acted as an "observer as participant" (Mertler, 2008, p. 81), and field notes. These methods were used since interviews allow for the collection of information that cannot be observed, such as the participants' feelings and their interpretations of certain situations. Observations were used since they allowed the researcher to observe different things that may have become ordinary to the individuals involved in that particular setting or context. Also, field notes were written in order to record aspects of the observations. The field notes included aspects such as the participants' and even the researcher's behavior, as well as the researcher's personal reflections. 


\section{Data Analysis}

In order to analyze the data, both microanalysis and constant comparative analysis (Strauss \& Corbin, 1998) were used to identify if the novice teachers had employed any of the emotional regulation strategies proposed by Gross (1998), and Sutton (2004). Microanalysis is "the detailed line-by-line analysis necessary at the beginning of the study to generate initial categories (with their properties and dimensions) and to suggest relationships among categories" (Strauss \& Corbin, 1998, p. 57).

This consisted of carefully reading each line and sentence of the data, and highlighting and reflecting on the words and turns of phrase that either the informant had emphasised in some way or that was identified as an interesting choice of words. All this was noted on the right hand side of the transcript. In addition, the emergent categories or sub-categories were labelled after considering the following questions: What is the informant actually referring to? What does this mean for the informant? How does this affect or influence the informant? What are we learning from this?

Then, the data were analysed again by employing a constant comparative method (Strauss \& Corbin, 1998), by which one set of data was analysed and then a second set was analysed with the first one in mind. By these means, the regulation strategies these novice teachers had employed were identified.

\section{Context}

The context of this research involved three different public schools: two primary schools and a government center for children, all in a large city in southwest Mexico, where five novice EFL teachers were facing teaching for the first time. Two of the novices were teaching at the same public primary school, and both had between 30 and 35 children in each of their groups. Another of the novices was teaching at a different public primary school, and had 27 students, one of whom was a student with Down syndrome. The remaining two novices were teaching at a government center for children. In this center there are different workshops, such as music, reading, arts, gymnastics, and English. One of these two novices had 23 students; the other had 20 students in his/her group. All five teachers had to elaborate the material they needed for their classes as there was no specific textbook allocated at these schools for teaching EFL. Thus these novice teachers used photocopies of different pages from diverse books or some exercises from various web sites.

\section{Participants}

In order to carry out this research, five novice teachers, around 21 and 22 years old, were chosen by means of convenience sampling owing to their accessibility and proximity to the researchers. For ethical reasons, pseudonyms replace the participants' real names in the 
findings section. These novice teachers study English at the same public university and were giving classes as part of their internship in the aforementioned schools. Prior to this internship, they had had some training to become teachers at the university, including different courses on how to teach such as Teaching Learning in English, Methods and Approaches of Teaching English, Teaching English to Children, and Planning of Teaching Practice, among others. However, they had not had any experience in actual teaching until their internship.

An interesting detail to mention at this point is that these five participants claimed to have a vocation for teaching. Their sense of vocation was perceived during their interviews when the teachers reported to like the idea of sharing their knowledge with their students. For example, Isabel stated that:

I am passionate about teaching, I like being in contact with children and I like the idea that I transmit knowledge to them. (Isabel, Interview) ${ }^{1}$

In addition, María said she enjoys designing material and teaching children something new as she expressed in the following extract:

I like teaching; I like being in front of a classroom and talking with the children and teaching them something, bringing them something new. I like to stay awake at night so I can elaborate my material. (María, Interview)

Moreover, they also expressed that they knew they wanted to be teachers at an early age. For instance, Sofía affirmed that:

This is one of the things that I like the most...I always wanted to be a teacher... since I was a little girl...now that I find myself in front of a group, I like it, I feel comfortable. (Sofía, Interview)

As seen from the above, it seems that these novice teachers appeared to share a calling for teaching and, in general, enjoy teaching. This reinforces the idea of Day and Qing (2011), who state that "many teachers enter the profession with a sense of vocation and with a passion to give their best to the learning and growth of their pupils" (p. 29). From this, it may be inferred that when novice teachers have a sense of vocation and a passion for teaching, they are more likely to experience positive emotions. However, just because a teacher has a vocation, or says $\mathrm{s} /$ he likes teaching, there is no guarantee that $\mathrm{s} /$ he will experience only positive emotions. As will be shown later, these participants experienced some negative emotions also.

\section{Procedure}

The first step in the research was to gain permission to carry out this inquiry. Once this was achieved, the participants were selected by means of convenience sampling which

1 The excerpts were translated from Spanish. 
involves drawing elements from a group that is easily accessible to the researcher (Tashakkori \& Teddlie, 2003). After this, the researcher interviewed the participants, transcribed the interviews, and observed their classes. The data generated from the interviews and the observations of the classes were then analyzed by using aspects of Grounded Theory. First the data were initially coded to identify emerging categories then those data were compared and analyzed to finally arrive at the study's definite categories.

\section{Findings}

During the analysis of the data, the regulation strategies that the novice EFL teachers use to manage their negative emotions emerged. These emotional regulation strategies, two preventative and two responsive, are presented in Table 1.

Table 1. Analysis Based on Definitions by Gross (1998) and Sutton (2004)

\begin{tabular}{|l|l||}
\hline Preventative & selecting situations \\
\hline Preventative & cognitive change \\
\hline Responsive & modifying the emotional experience \\
\hline Responsive & modifying the emotional expression \\
\hline
\end{tabular}

\section{Selection of Situations}

According to Gross (1998), there are different strategies that can be used in order to modify and control the emotions we experience. One strategy is selecting situations. For instance, a novice EFL teacher may choose to work only with children, instead of teenagers or adults, because s/he may think it is easier to manage and work with them. They may arrive at this decision because as they are novices, they may lack confidence in their language and/or teaching ability. In other words, s/he chooses to work with children in order to avoid possibly negative emotions especially regarding themselves.

The novice teachers that participated in this inquiry seem to have used this strategy. This can be noticed when they said that they prefer working with children, and that was why they had chosen to do their internship working with children. For example, Isabel mentioned:

Well I prefer the kids, I would not mind working with teenagers or young adults, but I prefer children because they are so cute, and well, I think I do better with children, that is why I wanted to work with children in my social service. (Isabel, Interview) 
When novice teachers begin teaching for the first time, they arrive at their schools with certain expectations. They have been thinking about what teaching would be like. They have assumptions concerning what their students will be like and how they will act. In the extract above, Isabel seems to have thought that she could "do better with children" which may infer that she did not have enough confidence in herself to teach teenagers or adults.

\section{Cognitive Change}

Gross (1998) includes cognitive change in his classification of emotional regulation. Cognitive change occurs when the teacher realizes that a child misbehaves because s/he has troubles at home. As a result of cognitive change, the teacher assesses the situation again and, instead of anger, the teacher feels empathy. It seems that one of the novice teachers that participated in this inquiry had gone through a cognitive change with one of her students. Paula said:

A boy told me that his mother had died and he had no dad, then I was like, I don't know, what do you do when a child tells you something very personal? Well I told him that now his mom takes care of him in heaven, and that he has an angel in heaven. I tried to comfort him and now, I see him differently because I know what he is going through, so, when he does not want to participate or misbehaves, well, I understand him. (Paula, Interview)

In the previous extract, it is possible to see how instead of being angry or disappointed at the child's misbehavior or lack of participation, the teacher tries to understand her student. This cognitive change could be interpreted as emotional understanding (Denzin, 1984). In this teacher's case, the emotional understanding occurred because the teacher was empathetic with her student.

\section{Modification of Emotional Experience}

When people do something for the very first time, it is normal to be nervous and teaching is no exception. The novice teachers reported being nervous during the first days of their classes because it was a new experience for them. They were nervous because they were going into the unknown, the real world of teaching, and they did not know how they would manage being in charge of a group for the first time. For example, Sofia said:

It was the first time I found myself in front of a group of kids and it was my group, then my legs, hands and everything were shaking. At the moment that I introduced myself with them I felt anxious to know what would be their reaction when they meet me. (Sofía, Interview)

In the previous extract it is clear that Sofia was really nervous, however, instead of letting this emotion interfere with her performance, she modified her emotional experience. According to Gross (1998) an emotional experience may be modified by self-talk, which is exactly what Sofia did. 
I tried not to panic and to concentrate. I told myself in my mind I say, "I can, I can, I can." (Sofía, Interview)

This teacher seemed to have modified her emotional experience by using self-talk to encourage herself. This is emphasized by the fact she said three times "I can." Therefore, it appears that Sofia used an emotional regulation strategy and also emotional intelligence. One of the characteristics of emotional intelligence, according to Goleman (2005), is to motivate oneself in order to achieve a goal. Self-talk is one of the alternatives at people's disposal when seeking to achieve this kind of motivation.

Another example is María's case. She becomes angry at a particular child who appears not to listen to her, who does not obey the rules, and who does not respect her authority in the classroom. Maria reported:

Sometimes I get angry because I have a child with Down syndrome and he is not easy to deal with, he always makes me angry and he does not let me work with the group. He is very restless, he does not know how to obey, he does not respect rules or authority, he sees everything as a game and he is always throwing me something, there is not a day in which he does not throw something at me or erase something from the board, that is, he makes me angry! (María, Interview)

On the one hand, it is important to take into consideration that working with a child who has Down syndrome may be particularly challenging, but on the other hand, there is often a difficult student in each group and s/he can make the teacher feel there is a lack of control. As a result, the teacher may think that s/he is incompetent as a teacher. However, María decided to see the situation in a different way. She modified the way she was experiencing that emotion. She explained that when dealing with negative emotions she does the following:

I repeat to myself that I have to calm down...I look at the clock and I do not mind if there are 50 minutes left, I tell myself that the class is almost over and that I just have to deal with that situation for a little longer. (María, Interview)

María, as well as Sofía, modified her emotional experience by using self-talk. She tried to think that the situations that she was experiencing would last only for a little bit longer. Therefore, even though teachers experience negative emotions, it seems they are capable of controlling these emotions by modifying the emotional experience or the emotional expression.

\section{Modification of Emotional Expression}

The first time novice teachers meet their students is particularly significant. It is the beginning of their time together and it is when everything starts. For students it may be just another English course, but for novice teachers it is the beginning of their journey in the 
world of teaching. That is why the first day matters a lot; however, it is not always easy. For example, Isabel expresses:

The first day, when I met my children, well, they asked me a lot of things! "How old are you?", "where did you work before?", "what things do you like", "how do you say this and that in English." They just kept asking me things and they were all looking at me, waiting for answers, they were like fireflies. That made me really nervous. (Isabel, Interview)

It seems that Isabel went through a difficult time during her first lesson, but she managed the situation by acting calmly. She explains:

I acted calm, you know, as if I had experience, I gave the impression of having self-confidence and being a calm teacher, but the truth is that I was nervous. The children were looking me in the eye, they were like fireflies, like lights looking at me, but I acted very calmly. (Isabel, Interview)

In order to perform her job, Isabel had to act as if she were calm and show self-confidence even though she did not feel it. In other words, she modified her emotional expression. It may be thought that modifying emotional expression consists of not showing oneself angry or nervous, but having a happy face with a big smile. However, modifying the emotional expression does not only consist of smiling; it may consist of showing self-confidence. Furthermore, modifying emotional expression is part of emotional labor. This involves people manufacturing or masking their emotions in order to perform their job, in this case, teaching a class. As Hargreaves (1998) states, emotional labor is not "just acting out feelings superficially like pretending to be disappointed or surprised, but also consciously working oneself up into a state of actually experiencing the necessary feelings that are required to perform one's job well" (p. 840).

Teachers manufacture and mask their emotions in different situations in order to generate a response in their students. In this way, Paula explains that if a teacher wants students to have confidence in her, then they must look like confident teachers and that is the reason she controls her expression. She says:

To appear to be confident helps the children to have confidence in you as a teacher, you must not look nervous because they will attack you; that is why even though I'm nervous I don't let them notice it. I act calm and with a lot of confidence in myself, it does not matter if I'm nervous inside, I do not show it. (Paula, Interview)

\section{Conclusion}

Based on the assumption that emotions cannot be separated from the act of teaching (Hargreaves, 2000), the main objective of this research was to discover if, and how, novice EFL teachers regulate their negative emotions during their initial teaching practice. From the data that were generated, it can be deduced that the novice teachers in this study had felt nervous during their initial practice possibly because since they were new to the profession, 
they had lacked self-confidence. In addition, they had felt angry or frustrated at times because some students did not seem to respect them as the authority in the classroom as they had expected. In order to manage these emotions, these novice EFL teachers appear to have employed both preventative and responsive emotional regulation strategies. These included selecting situations, a cognitive change, modifying their emotional experience, and modifying their emotional expression.

In the case of these novice teachers, the choice to select a situation appears to have been influenced by a novice teacher's image of his/her professional identity. If the teacher has low self-confidence regarding his/her teaching and/or language ability then s/he may try to avoid working with students of a certain age and/or language level so as not to feel challenged or perhaps even threatened. The other emotional strategies the novice teachers employed are perhaps not that straightforward given that they require emotional understanding when understanding and being empathetic with their students, emotional intelligence when motivating themselves, and emotional labor when manufacturing or masking their own emotions; all of which are necessary attributes and/or processes not only in a novice teacher's practice, but in any teacher's daily practice.

\section{Implications}

Teaching is a very demanding job that has both rewards and challenges. It can be specially demanding for a novice EFL teacher given that everything that occurs in the classroom is new. Even more, novice teachers have to deal with different situations at the same time. When they start teaching they have to face reality and see whether or not the expectations they had about teaching match their reality, and if not, cope with what they discover. Moreover, they have to deal with the unexpected situations that teaching involves. This may be particularly difficult, as novice teachers are usually taught how to teach in a very controlled setting, and they do not know how to react when feeling certain emotions. In the same manner, they have to face and regulate their emotions in order to continue with the class. Therefore, novice teachers should be taught about the emotional dimension that teaching entails. Perhaps more importantly, they should be made aware of the considerable amount of daily emotional labor that teaching involves, as well as how to regulate their emotions when necessary. Arguably, if teachers knew about the emotional dimension of teaching and the possible emotional regulation strategies they could use, their practice could change and perhaps improve as they would be forewarned, and therefore forearmed that teaching requires more than simply designing a good lesson plan and using appropriate teaching strategies. It is a profession that also requires teachers to regulate their emotions and understand, as well as respond to those of others, in a proper manner in order to promote and facilitate learning. 


\section{References}

Baier, A. (2004). Feelings that matter. In R. C. Solomon (Ed.), Thinking about feelings: Contemporary philosophers on emotion (pp. 200-213). New York, NY: Oxford University Press.

Bullough, R. V. (2011). Seeking eudaimonia: The emotions in learning to teach and to mentor. In P. A. Schutz \& M. Zembylas (Eds), Advances in teacher emotion research: The impact on teachers' lives (pp. 33-53). New York, NY: Springer.

Day, C., \& Qing, G. (2011). Teacher emotions: Well-being and effectiveness. In P. A. Schutz \& M. Zembylas (Eds), Advances in teacher emotion research: The impact on teachers' lives (pp. 15-31). New York, NY: Springer.

Denzin, N. K. (1984). On understanding emotion. San Francisco, CA: Jossey-Bass.

Flick, U. (2009). An introduction to qualitative research (4th ed.). California, CA: Sage publications.

Fried, L. (2011). Teaching teachers about emotion regulation in the classroom. Australian Journal of Teacher Education, 36(3).

Goleman, D. (2005). Emotional intelligence: 10th anniversary edition. New York, NY: Bantam Books.

Gross, J. J. (1998). The emerging field of emotion regulation: An integrative review. Review of General Psychology, 2(3), 271-299. http://dx.doi.org/10.1037/1089-2680.2.3.271.

Gross, J. J. (2002). Emotion regulation: Affective, cognitive and social consequences. Psychophysiology, 39(3), 281-291. http://dx.doi.org/10.1017/S0048577201393198.

Hargreaves, A. (1998). The emotional practice of teaching. Teaching and Teacher Education, 14(8), 835-854. http://dx.doi.org/10.1016/S0742-051X(98)00025-0.

Hargreaves, A. (2000). Mixed emotions: Teachers' perceptions of their interactions with students. Teaching and Teacher Education, 16(8), 811-826. http://dx.doi.org/10.1016/ S0742-051X (00)00028-7.

Hargreaves, A. (2001). The emotional geographies of teaching. Teachers' College Record, 103(6), 1056-1080.

Isenbarger, L., \& Zembylas, M. (2006). The emotional labor of caring in teaching. Teaching and Teacher Education, 22(1), 120-134. http://dx.doi.org/10.1016/j.tate.2005.07.002.

Linnenbrink, E. A. (2006). Emotion research in education: Theoretical and methodological perspectives on the integration of affect, motivation, and cognition. Educational Psychology Review, 18(4), 307-314. http://dx.doi.org/10.1007/s10648-006-9028-x.

Méndez, M. G., (2011). The motivational properties of emotions in foreign language learning. Colombian Applied Linguistics Journal, 13(2), 43-59.

Méndez, M. G., \& Fabela, M. A. (2014). Emotions and their effects in a language learning Mexican context. System, 42, 298-307. http://dx.doi.org/10.1016/j.system.2013.12.006.

Méndez, M. G., \& Peña, A. (2013). Emotions as learning enhancers of foreign language learning motivation. PROFILE Issues in Teachers' Professional Development, 15(1), 109-124.

Merriam, S. B. (2002). Qualitative research in practice: Examples for discussion and analysis. San Francisco, CA: Jossey-Bass.

Mertler, C. A. (2008). Action research: Teachers as researchers in the classroom. Thousand Oaks, CA: Sage. 
Nias, J. (1996). Thinking about feeling: The emotions in teaching. Cambridge Journal of Education, 26(3), 293-306. http://dx.doi.org/10.1080/0305764960260301.

Ryan, K. (1986). The induction of new teachers. Bloomington, IN: Phi Delta Kappa Educational Foundation.

Salovey, P., \& Mayer, J. D. (1990). Emotional intelligence. Imagination, Cognition, and Personality, 9, 185-211. http://dx.doi.org/10.2190/DUGG-P24E-52WK-6CDG.

Schutz, P. A, \& Lanehart, S. L. (2002). Introduction: Emotions in education. Educational Psychologist, 37(2), 67-68. http://dx.doi.org/10.1207/S15326985EP3702_1.

Schutz, P. A., \& Pekrun, R. (Eds). (2007). Emotion in education. Boston, MA: Academic Press.

Straus, A., \& Corbin, J. (1998). Basics of qualitative research: Techniques and procedures for developing grounded theory. Thousand Oaks, CA: Sage.

Sutton, R. E. (2004). Emotional regulation goals and strategies of teachers. Social Psychology of Education, 7, 379-398. http://dx.doi.org/10.1007/s11218-004-4229-y.

Tashakkori, A., \& Teddlie, C. (2003). Handbook of mixed methods in social \& behavioral research. Thousand Oaks, CA: Sage.

Twenge, J. M., \& Baumeister, R. F. (2002). Self-control: A limited yet renewable resource. In Y. Kashima, M. Foddy, \& M. J. Platow (Eds.), Self and identity: Personal, social, and symbolic (pp. 57-70). Mahwah, NJ: Lawrence Erlbaum.

van Veen, K., \& Lasky, S. (2005). Emotions as a lens to explore teacher identity and change: Different theoretical approaches. Teaching and Teacher Education, 21(8), 895-898. http://dx.doi.org/10.1016/j.tate.2005.06.002.

\section{The Authors}

Silvia Arizmendi Tejeda has recently been awarded a BA in English Language by Universidad Veracruzana (Mexico). At present she is collaborating with the Research Group Educational Processes.

Barbara Scholes Gillings de González is a longstanding teacher at Universidad Veracruzana (Mexico), where she has helped in the design of the in-house and virtual BAs, and MA programmes. She has a $\mathrm{PhD}$ in Education awarded by Exeter University, England.

Cecilio Luis de Jesús López Martínez has a PhD in Language Studies awarded by the University of Kent, England. He helped design and implement the MA in TESOL at Universidad Veracruzana (Mexico). He is leader of the Research Group Educational Processes. 


\section{Appendix: Interview Guide}

\begin{tabular}{|c|c|}
\hline \multicolumn{2}{|c|}{ What is the nature of novice EFL teachers' emotions during their initial practice? } \\
\hline $\begin{array}{l}\text { How do novice teachers } \\
\text { feel during their initial } \\
\text { practice? }\end{array}$ & $\begin{array}{l}\text { - Do you enjoy teaching? Why or why not? } \\
\text { - When you think about emotions and teaching what comes to mind? } \\
\text { - How do you feel when you are in the classroom? } \\
\text { - Have you ever felt any of these emotions when teaching: anger, fear, } \\
\text { sadness, joy, surprise, love/affection? Can you describe the situation in } \\
\text { which you feel like this? }\end{array}$ \\
\hline $\begin{array}{l}\text { Do novice teachers } \\
\text { regulate their emotions } \\
\text { during their classes? If so, } \\
\text { how? }\end{array}$ & $\begin{array}{l}\text { - You said you felt like this when... what did you do in that situation? } \\
\text { - Do you let your students know how you feel? Why? If not, how do you } \\
\text { behave so that they do not know how you feel? } \\
\text { - Let's say that you feel very anxious because you asked the group to } \\
\text { work in teams and you lost control of the classroom. What would you } \\
\text { do? }\end{array}$ \\
\hline $\begin{array}{l}\text { When and why do novice } \\
\text { teachers regulate their } \\
\text { emotions? }\end{array}$ & $\begin{array}{l}\text { - You said you let/don't let your students know how you feel. Do you do } \\
\text { this always? I mean, you choose to hide your emotions all the time or } \\
\text { just when you consider them to be negative? Why or why not? } \\
\text { - Do you ever worry that when you are angry or anxious you may cross } \\
\text { some line? }\end{array}$ \\
\hline $\begin{array}{l}\text { What impact does } \\
\text { emotion regulation have } \\
\text { on teachers' practice? }\end{array}$ & $\begin{array}{l}\text { - What are the consequences of controlling or not controlling your } \\
\text { emotions when teaching? } \\
\text { - In what way have your classes changed because of your feelings? } \\
\text { - Once a teacher told me that when he was angry he monitored his } \\
\text { students very closely. Have you ever done anything similar? }\end{array}$ \\
\hline
\end{tabular}

